\title{
Study on the Optimization for the Extraction Process of Andrographolide by Ultrasonic Assisted Extraction
}

\author{
KiBong Kim ${ }^{1}$, IlJin Kim ${ }^{1}$, SongLok $\mathrm{Uh}^{1}$, YongIl Seo ${ }^{1}$, CholKwang Li ${ }^{1}$, UnHyang Lyeom², KwangRyel Hwang² \\ 'Pyongyang Jang Chol Gu University of Commerce, Pyongyang, Democratic People's Republic of Korea \\ 2Pyongyang Technology College of Food and Commodity, Pyongyang, Democratic People's Republic of Korea
}

\begin{abstract}
Article Info

Volume 8 Issue 2

Page Number : 08-17

Publication Issue :

March-April-2021

\section{Article History}

Accepted : 01 March 2021

Published : 07 March 2021

Because andrographis has a long history of folk medicine in Southeast Asian co untries with antibacterial, antipyretic, antineoplastic, anti-inflammatory, cardi oprotective effect and so on, the areas where andrographolia is introduced and cultivated are mainly concentrated. Espically andrographolide, neoandrograph olide, andrographiside, homoandrographolide, andrographane, andrographani $\mathrm{n}$, andrographone and andrographosterol that is concentrated in the leaves of $\mathrm{t}$ he plant play the main medical role of andrographis. Of the above chemicals, a ndrographolide is the major bioactive constituent responsible for variety of acti vities. Leaves and stems of plant are used for extracting active phytochemicals; roots are used rarely. In this study, improved the extractability of andrographol ide from the A. paniculata by ultrasonic assisted extraction, the optimum condi tion for extracted the andrographolide is determined by response surface experi ment and detected the extractability of andrographolide under the optimum co ndition. By single factor analysis and response surface experiments, the optimu $\mathrm{m}$ conditions for extracted the andrographolide were the extraction solution co ncentration $62.8 \%$, the ultrasonic extraction time $59 \mathrm{~min}$, the ratio of solid to li quid $1: 10.5$ and the extraction temperature $62^{\circ} \mathrm{C}$. Investigate the andrographoli de extractability in the optimun extraction condition by HPLC were increased $\mathrm{f}$ rom $2.27 \%$ to $3.28 \%$.

Keywords: Andrographis, Extraction, Andrographolide, Response Surface Expe riments, Ultrasonic Assisted Extraction
\end{abstract}

\section{INTRODUCTION}

Andrographis paniculata (Burm.f.) Wall. ex Nees, (En glish name- King of Bitters) is an herbaceous plant. I t belongs to Acanthaceae family, it has a long history of folk medicine in Southeast Asian countries and is o ne of the most representative "Great Southern Medici ne". It is native to India and Sri Lanka, and it is also fo und in abundance in Asian countries such as India, $\mathrm{Pa}$ kistan, Malaysia and Indonesia. It is cultivated extensi vely in China and Thailand, the East and West Indies, and Mauritius. Andrographis paniculata Nees, named as "Chuan Xin Lian" in Chinese, is a traditional Chine se medicine to treat sore throat, flu, and upper respira

Copyright: (C) the author(s), publisher and licensee Technoscience Academy. This is an open-access article distributed under the terms of the Creative Commons Attribution Non-Commercial License, which permits unrestricted non-commercial use, distribution, and reproduction in any medium, provided the original work is properly cited 
tory tract infections. Prior researchers have deepened on andrographis's research since they recognized that the andrographis is an important substance that gives the main biological activity of life. It is normally grow $\mathrm{n}$ from seeds and grows in pine, evergreen and decidu ous forest areas, and also along roads and in villages [1]. Andrographis paniculata (AP) possesses many me dicinal benefifits due to the presence of various terpe ne compounds such as andrographolide (AND), 14-de oxy-11, 12-didehydroandrographolide (DDA), neoand rographolide (NEA), and andrograpanin[2]. In additio $\mathrm{n}$ to andrographolide induces cell cycle arrest and apo ptosis, and reduces migration, invasion, and metallopr oteinase expression in human rheumatoid fibroblast-li ke synoviocytes[3]. In the many kinds of traditional C hinese medicine preparation of the main raw material, AP can be used in respiratory tract infection, and gast roenteritis, hypertension, malaria, there are "Chinese medicine antibiotics," said. Phytochemical investigati ons on this genus have indicated that diterpenoids are the major constituents [4-6], such as andrographolide, isoandrographolide, neoandrographolide, and bisandr ographolides A-C. Furthermore, some of them showe $\mathrm{d}$ a variety of pharmacological effects, including antivi ral [7], anti-proliferation [8], and anti-inflammatory a ctivities [9-11], as well as activation on TRPV channel $\mathrm{s}$ [12]. And the bioactives are present in medicinal pla nts but in low concentration and hence a proper extra ction method needs to be developed to extract maxim um bioactives from plants. Extraction of andrographol ide from A. paniculata has been investigated in the pa st focusing mainly on conventional solvent extraction. Various modern extraction techniques such as micro wave-assisted extraction (MAE), supercritical fluid ext raction (SCFE) and ultrasonic assisted extraction (UA E) have also been developed recently for its efficient e xtraction [13]. But the study to optimized ultrasonic a ssisted extractive process of andrographolide by respo nse surface experiments was not carried out previousl $y$. Therefore in this study, optimized the ultrasonic as sisted extractive process of andrographolide by respon se surface experiment and detected the extractability of andrographolide under the optimum condition by HPLC.

\section{METHODS AND MATERIAL}

\subsection{Materials}

\section{(1) Materials}

The Andrographis paniculata (Burm.f.) Nees were use $\mathrm{d}$ in this study were purchased from a local supermark et in Heilongjiang Province, China in 2020. 7.

(2) Reagents

Andrographolide standard (Aldrich 365645-100 mg, 9 $8 \%$ HPLC grade) was produced from Sigma-Aldrich i n 2020. 7.

Acetonitrile and ethanol were purchased from XinShe ng biological thechnology Co. Ltd in Heilongjiang Pro vince, China in 2020. 7.

\section{(3) Instruments}

QYTC type ultrasonic cleaning machine

HPLC (Agilent 1100)

MS205DU type electronic analytical balance

\section{(4) Period for experiment}

From Augest 2020 to December 2020, an experiment was conducted at Northeast Agricultural University of China.

\subsection{Method}

(1) Chromatographic condition and system adaptabilit $y$ test

Agilent TC-C18 column ( $4.6 \mathrm{~mm} \times 250 \mathrm{~mm}, 5 \mathrm{um})$, mo bile phase: acetonitrile-water (38:62), flow rate: $1.0 \mathrm{~m}$ $\mathrm{L} / \mathrm{min}$, column temperature was $25^{\circ} \mathrm{C}$, sample size $\mathrm{w}$ as $10 \mu \mathrm{L}$, detection wavelength was $225 \mathrm{~nm}$, new andr ographolide $210 \mathrm{~nm}$, dehydrated andrographolide 254 $\mathrm{nm}$. The theoretical plate number should be no less $\mathrm{t}$ han 2000 according to the peak of andrographolide, $d$ ehydrated andrographolide and neandrographolide [1 $3]$. 
(2) Preparation of reference solution

An appropriate amount of andrographolide, dehydrat ed andrographolide and neandrographolide was weig hed accurately, and methanol was added to prepare a mixed solution containing $0.1 \mathrm{mg}$ for each $1 \mathrm{~mL}$.

\section{(3) Preparation of test solution}

Sample was accurately weighed at $10 \mathrm{~g}$, and the extrac ted solution was extracted by different extraction met hods is maken at $100 \mathrm{~mL}$. Take $5 \mathrm{~mL}$ of superneutral al umina column, constant volume with $50 \%$ ethanol to $100 \mathrm{~mL}$, shake well, get.

\section{(4) Single factor experiments}

The effects of different extraction methods, different concentration of ethanol, different ultrasonic extratio $\mathrm{n}$ time, different ratio of solid to liquid and different extraction temperature on the total content of diterpe noid lactones (the sum of andrographolide, dehydrate $\mathrm{d}$ andrographolide and neandrographolide) of androgr apholide were investigated.

\section{(5) Response surface experiment}

Based on the results obtained from single factor analy sis, optimization was carried out by using Response su rface experiment to study the effect of four independe $n t$ variables $\left[\mathrm{X}_{1}\right.$ : concentration of ethanol, $\mathrm{X}_{2}$ : ultrason ic extration time, $\mathrm{X}_{3}$ : ratio of solid to liquid, $\mathrm{X}_{4}$ : extrac tion temperature]. The Surface Response Methodolog $\mathrm{y}(\mathrm{RSM})$ is applied to the central composite design (C $\mathrm{CD}$ ) for the adaptation of a second order polynomial $b$ $\mathrm{y}$ the least square technique. Below equation is used $\mathrm{t}$ o determine the effects of test variables to the searche $\mathrm{d}$ responses (extractability) and the correlation betwe en variables.

$\mathrm{Y}=\beta_{0}+\sum_{\mathrm{i}=1}^{\mathrm{k}} \beta_{\mathrm{i}} \mathrm{X}_{\mathrm{i}}+\sum_{\mathrm{i} \leq \mathrm{j}}^{\mathrm{k}} \beta_{\mathrm{ij}} \mathrm{X}_{\mathrm{i}} \mathrm{X}_{\mathrm{j}}+\sum_{\mathrm{i}=1}^{\mathrm{k}} \beta_{\mathrm{ii}} \mathrm{X}_{\mathrm{i}}{ }^{2}+\epsilon$ where $\mathrm{Y}$ shows the dependent variable, $\beta_{0}, \beta_{0}$, $\beta_{\mathrm{i}}, \quad \beta_{\mathrm{ii}}$ and $\beta_{\mathrm{ij}}$ represent the regression coeffificients for constant, linear, quadratic, and interactive effects, respectively; $\mathrm{Xi}$ and $\mathrm{Xj}$ denote the independent varia bles.

The effects of the factors on the response were expres sed as surface and contour plots to visualize the relati onship between the response and the independent var iables and to acquire the optimal conditions of the pro cess.

\subsection{Statistical analysis}

All experiments were triplicated. Analysis of variance (ANOVA) of the results was performed using DesignExpert version 11. The statistical signifificance of the model terms was determined by calculating the $\mathrm{F}$-val ue at confidence levels of $95 \%(\mathrm{P}<0.05)$ and $99 \%(\mathrm{P}<0$. 01). To determine the differences between the control sample and the optimum condition extractability, SP SS version 26 and the independent T-test were used.

\section{RESULTS AND DISCUSSION}

\subsection{The results of single factor experiments}

\section{(1) Selection of ethanol concentration}

$10 \mathrm{~g}$ of sample was accurately weighed and soaked with $100 \mathrm{~mL}$ of $30 \%, 40 \%, 50 \%, 60 \%, 70 \%, 80 \%$, and $90 \%$ for $1 \mathrm{~h}$, respectively, and then extracted by ultrasonic cleaning machine for $1 \mathrm{~h}$ and the extraction temperature $60^{\circ} \mathrm{C}$. Total extractability of diterpenoid lactones were calculated under different ethanol concentrations, and the results were shown in Figure 1. 


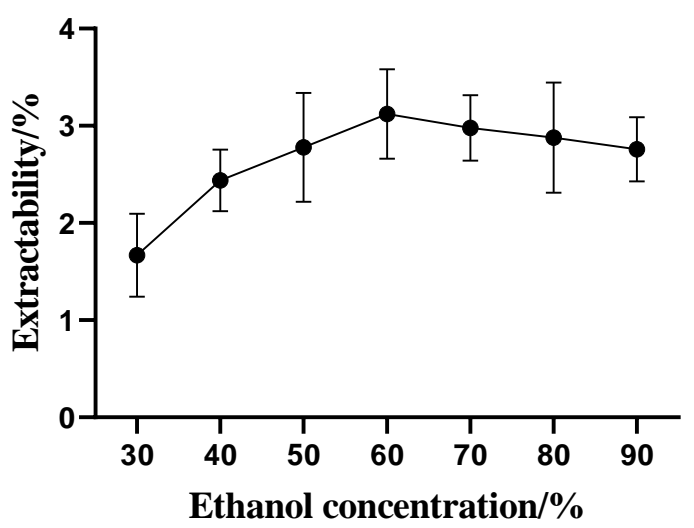

Figure 1. Comparison of total diterpene lactones extracted with different ethanol concentrations As can be seen from Figure 1, with the increase of eth anol concentration, diterpene lactones extractability $g$ radually increased, reaching the highest when the con centration was $60 \%$, and then the content decreased s lightly but remained at a stable level. Therefore, $60 \%$ ethanol was selected as the extraction solvent.

\section{(2) Selection of extraction time}

$10 \mathrm{~g}$ of sample was accurately weighed and soaked in $100 \mathrm{~mL} 60 \%$ ethanol for $1 \mathrm{~h}$, respectively, after ultras onic extraction for 30,60, 90, 120 and 150min, the ext ractability of diterpenoids extracted under different ul trasonic time was calculated, and the results were sho wn in Figure 2.

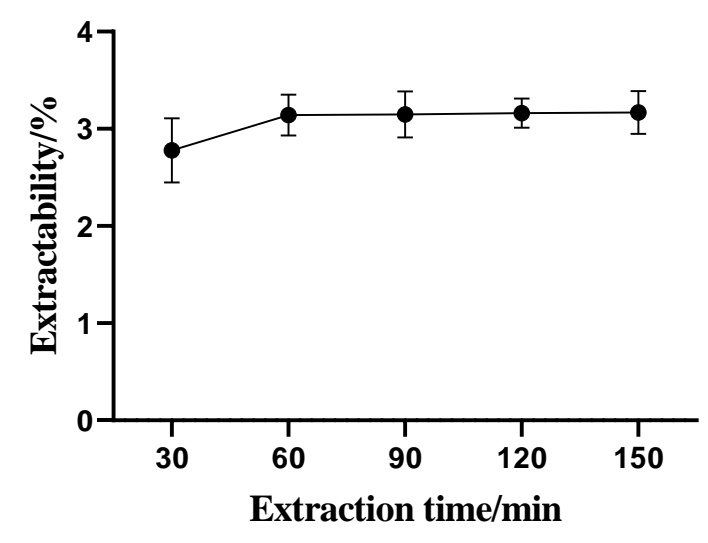

Figure 2. Comparison of total diterpene lactones extracted at different ultrasonic times
As can be seen from Figure 2, the total extractability o $\mathrm{f}$ diterpenoids gradually increased with the extension of extraction time, and difference between extractabil ity is rare after $1 \mathrm{~h}$. Considering the economy and hig $h$ efficiency of the extraction process, ultrasonic extra ction time of $1 \mathrm{~h}$ was selected.

(3) Selection of ratio of solid to liquid

$10 \mathrm{~g}$ of sample was accurately weighed and ultrasonic ally extracted with $60 \%$ ethanol at 50, 100, 200 and 25 $0 \mathrm{~mL}$ for $1 \mathrm{~h}$, respectively. The total extractability of $\mathrm{d}$ iterpene lactones at different ratio of solid to liquid $\mathrm{w}$ as calculated, and the results were shown in Figure 3.

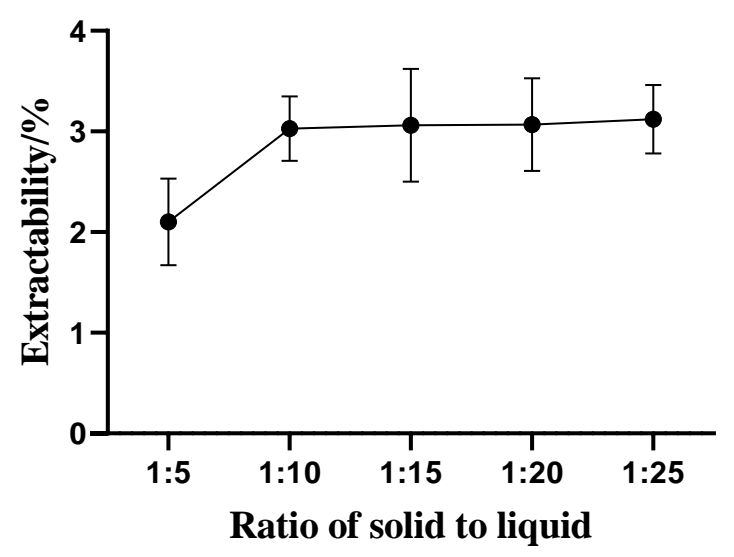

Figure 3. Comparison of total content of diterpene lac tones extracted by different ratio of solid to liquid

It can be seen from Figure 3, that the total extracta bility of diterpenoids gradually increased with the inc rease of ratio of solid to liquid, and difference betwee $\mathrm{n}$ extractability is rare after $1: 10$, considering the extr action process. The ratio of solid to liquid is selected 1: 10.

(4) Selection of extraction temperature

$10 \mathrm{~g}$ of sample was accurately weighed and soaked in $100 \mathrm{~mL} 60 \%$ ethanol in $40,50,60,70,80^{\circ} \mathrm{C}$ of extracti on temperature for $1 \mathrm{~h}$, respectively. The total extract ability of diterpene lactones at different extraction te mperature was calculated, and the results were shown in Figure 4. 


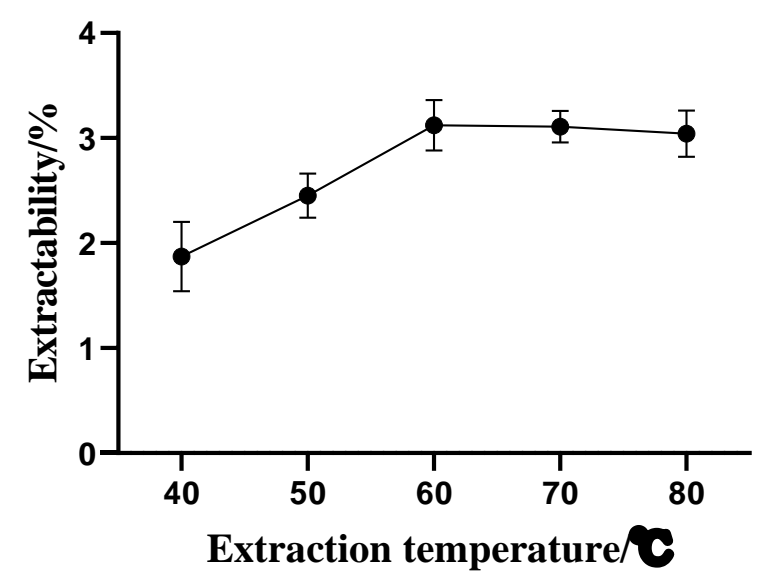

Figure 4. Comparison of total content of diterpene lac tones extracted by different extraction temperature
It can be seen from Figure 4, that the total extractabili ty of diterpenoids gradually increased with the increa se of extraction temperature, and the growth slowed $d$ own after $60^{\circ} \mathrm{C}$, considering the extraction process. $\mathrm{T}$ he extraction temperature is selected $60^{\circ} \mathrm{C}$.

\subsection{The results and analysis of Response surface experiment}

The range of the independent variables and their corr esponding levels is shown in Table 1.

Table 1. The range of the independent variables and their corresponding levels

\begin{tabular}{|c|c|c|c|c|c|c|}
\hline \multicolumn{2}{|c|}{ Code } & \multicolumn{5}{|c|}{ Coded levels } \\
\hline \multicolumn{7}{|l|}{ Independent } \\
\hline variables & Symbol & -2 & -1 & 0 & +1 & +2 \\
\hline \multicolumn{7}{|l|}{ Ethanol concentra } \\
\hline $\operatorname{tion} / \%$ & $\mathrm{X}_{1}$ & 40 & 50 & 60 & 70 & 80 \\
\hline \multicolumn{7}{|l|}{ Extraction } \\
\hline time/min & $\mathrm{X}_{2}$ & 40 & 50 & 60 & 70 & 80 \\
\hline \multicolumn{7}{|l|}{ Ratio of solid to li } \\
\hline quid & $\mathrm{X}_{3}$ & 8 & 9 & 10 & 11 & 12 \\
\hline \multicolumn{7}{|l|}{ Extraction temper } \\
\hline ature $/{ }^{\circ} \mathrm{C}$ & $\mathrm{X}_{4}$ & 20 & 40 & 60 & 80 & 100 \\
\hline
\end{tabular}

The results of central composite design (CCD) using the Design-Expert 11 software are shown in Table 2.

Table 2. Central composite design and Extractability

\begin{tabular}{|c|c|c|c|c|c|}
\hline \multirow[b]{2}{*}{ Runs } & \multicolumn{4}{|c|}{ Factors } & \multirow[b]{2}{*}{$\begin{array}{c}\text { Extractability } \\
\qquad / \%\end{array}$} \\
\hline & $\begin{array}{l}\mathrm{X}_{1}: \text { Ethanol } \\
\text { content } / \%\end{array}$ & $\begin{array}{l}\mathrm{X}_{2}: \text { Extract } \\
\text { Time/min }\end{array}$ & $\begin{array}{c}\mathrm{X}_{3} \text { : Ratio of solid to } \\
\text { liquid }\end{array}$ & $\begin{array}{c}\mathrm{X}_{4}: \text { Extract } \\
\text { Temperature/ } /{ }^{\circ} \mathrm{C}\end{array}$ & \\
\hline 1 & 50 & 50 & 9 & 40 & 2.81 \\
\hline 2 & 70 & 50 & 9 & 40 & 2.86 \\
\hline 3 & 50 & 70 & 9 & 40 & 2.82 \\
\hline 4 & 70 & 70 & 9 & 40 & 2.84 \\
\hline 5 & 50 & 50 & 11 & 40 & 2.93 \\
\hline 6 & 70 & 50 & 11 & 40 & 3.17 \\
\hline
\end{tabular}




\begin{tabular}{cccccc}
7 & 50 & 70 & 11 & 40 & 2.97 \\
8 & 70 & 70 & 11 & 40 & 3.15 \\
9 & 50 & 50 & 9 & 80 & 3.09 \\
10 & 70 & 50 & 9 & 80 & 2.9 \\
11 & 50 & 70 & 9 & 80 & 3 \\
12 & 70 & 70 & 9 & 80 & 2.83 \\
13 & 50 & 50 & 11 & 80 & 3.13 \\
14 & 70 & 50 & 11 & 80 & 3.16 \\
15 & 50 & 70 & 11 & 80 & 2.94 \\
16 & 70 & 70 & 11 & 80 & 3.03 \\
17 & 40 & 60 & 10 & 60 & 2.83 \\
18 & 80 & 60 & 10 & 60 & 3 \\
19 & 60 & 40 & 10 & 60 & 3.93 \\
20 & 60 & 80 & 10 & 60 & 3.01 \\
21 & 60 & 60 & 8 & 60 & 3.83 \\
22 & 60 & 60 & 12 & 60 & 2.92 \\
23 & 60 & 60 & 10 & 20 & 3.1 \\
24 & 60 & 60 & 10 & 100 & 3.26 \\
25 & 60 & 60 & 10 & 60 & 3.3 \\
26 & 60 & 60 & 10 & 60 & 3.29 \\
27 & 60 & 60 & 10 & 60 & 3.23 \\
28 & 60 & 60 & 10 & 60 & 3.26 \\
\hline 29 & 60 & & 60 & \\
\hline
\end{tabular}

※enter points is 5

The Design-Expert version 11 software was used to conduct square error analysis on the data in Table 2, and th e results were shown in Table 3. Taking ethanol concentration $\left(\mathrm{X}_{1}\right)$, extraction time $\left(\mathrm{X}_{2}\right)$, ratio of solid to liquid $\left(\mathrm{X}_{3}\right)$ and extraction temperature $\left(\mathrm{X}_{4}\right)$ as the influencing factors, and the extractability $(\mathrm{Y})$ as the response value, $\mathrm{t}$ he multiple quadratic regression equation for optimization for the extraction process of Andrographolide by ult rasonic assisted extraction was as below equation:

$$
\begin{gathered}
\mathrm{Y}=3.268+0.025 \mathrm{X}_{1}-0.013 \mathrm{X}_{2}+0.073 \mathrm{X}_{3}+0.037 \mathrm{X}_{4}+0.051 \mathrm{X}_{1} \mathrm{X}_{3}-0.045 \mathrm{X}_{1} \mathrm{X}_{4}-0.008 \mathrm{X}_{2} \mathrm{X}_{3}-0.03 \mathrm{X}_{2} \mathrm{X}_{4}-0.028 \mathrm{X}_{3} \mathrm{X}_{4}-0.085 \mathrm{X}_{1}^{2}-0.07 \\
1 \mathrm{X}_{2}{ }^{2}-0.08 \mathrm{X}_{3}{ }^{2}-0.061 \mathrm{X}_{4}{ }^{2}
\end{gathered}
$$

The correction coefficient of the model $\mathrm{R}^{2}=0.9523$ and $\mathrm{R}_{\mathrm{Adj}}{ }^{2}=0.9046$ indicate that the model has good fitting deg ree and small experimental error, so the model is suitable

Table 3. Analysis of variance of central composite design (CCD)

\begin{tabular}{c|c|c|c|c|c|c}
\hline Source & Sum of Squares & $\mathrm{df}$ & Mean Square & F-value & p-value & significant \\
\hline Model & 0.6611 & 14 & 0.0472 & 19.96 & $<0.0001$ & $* *$
\end{tabular}




\begin{tabular}{|c|c|c|c|c|c|c|}
\hline $\mathrm{X}_{1}$-Ethanol content & 0.0145 & 1 & 0.0145 & 6.13 & 0.0267 & $*$ \\
\hline $\mathrm{X}_{2}$-Extract Time & 0.0040 & 1 & 0.0040 & 1.69 & 0.2143 & \\
\hline $\mathrm{X}_{3}-$ Ratio of solid to liquid & 0.1276 & 1 & 0.1276 & 53.94 & $<0.0001$ & $* *$ \\
\hline $\mathrm{X}_{4}$-Extract Temperature & 0.0330 & 1 & 0.0330 & 13.95 & 0.0022 & $* *$ \\
\hline $\mathrm{X}_{1} \mathrm{X}_{2}$ & $6.250 \mathrm{E}-06$ & 1 & $6.250 \mathrm{E}-06$ & 0.0026 & 0.9597 & \\
\hline $\mathrm{X}_{1} \mathrm{X}_{3}$ & 0.0431 & 1 & 0.0431 & 18.20 & 0.0008 & $* *$ \\
\hline $\mathrm{X}_{1} \mathrm{X}_{4}$ & 0.0333 & 1 & 0.0333 & 14.08 & 0.0021 & $* *$ \\
\hline $\mathrm{X}_{2} \mathrm{X}_{3}$ & 0.0011 & 1 & 0.0011 & 0.4465 & 0.5149 & \\
\hline $\mathrm{X}_{2} \mathrm{X}_{4}$ & 0.0150 & 1 & 0.0150 & 6.34 & 0.0246 & $*$ \\
\hline $\mathrm{X}_{3} \mathrm{X}_{4}$ & 0.0127 & 1 & 0.0127 & 5.35 & 0.0364 & $*$ \\
\hline $\mathrm{X}_{1}^{2}$ & 0.1876 & 1 & 0.1876 & 79.27 & $<0.0001$ & $* *$ \\
\hline $\mathrm{X}_{2}{ }^{2}$ & 0.1318 & 1 & 0.1318 & 55.71 & $<0.0001$ & $* *$ \\
\hline $\mathrm{X}_{3}{ }^{2}$ & 0.1661 & 1 & 0.1661 & 70.22 & $<0.0001$ & $* *$ \\
\hline $\mathrm{X}_{4}{ }^{2}$ & 0.0974 & 1 & 0.0974 & 41.17 & $<0.0001$ & $* *$ \\
\hline Residual & 0.0331 & 14 & 0.0024 & & & \\
\hline Lack of Fit & 0.0300 & 10 & 0.0030 & 3.90 & 0.1007 & not significant \\
\hline Pure Error & 0.0031 & 4 & 0.0008 & & & \\
\hline Cor Total & 0.6942 & 28 & & & & \\
\hline
\end{tabular}

$※^{* *}$ means that it has a very significant effect on the results $(\mathrm{P}<0.01)$

* means that it has a significant effect on the results $(\mathrm{P}<0.05)$

As can be seen Table 3, the model F-value of 19.96 with a low probability $\mathrm{P}$-value of less than 0.0001 indicted $\mathrm{h}$ igh signifificance of the model. The lack of fit for an F-value of 3.90 meant that this term was not signifificantly relative to the pure error, the nonsignifificant value of lack fit $(>0.05)$ showed that the quadratic model was val id for this study. From the results in Table 3, the ratio of solid to liquid and the extract temperature had high si gnificant effects on the total extractabilty of diterpenoids $(\mathrm{p}<0.01)$, then the ethanol content had significant effe $\operatorname{cts}(\mathrm{P}<0.05)$, and the extract time had no significant effects $(\mathrm{P}>0.05)$. 


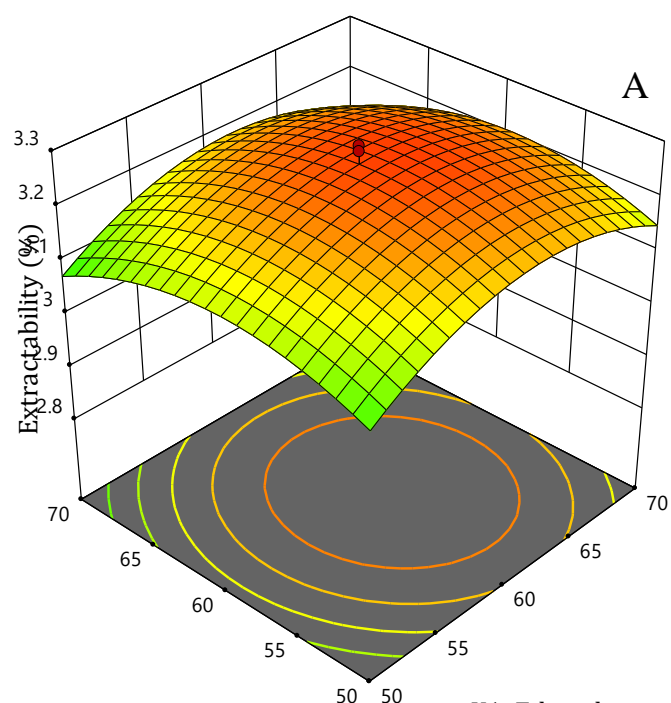

X2: Extract Time (min)

X1: Ethanol content (\%)

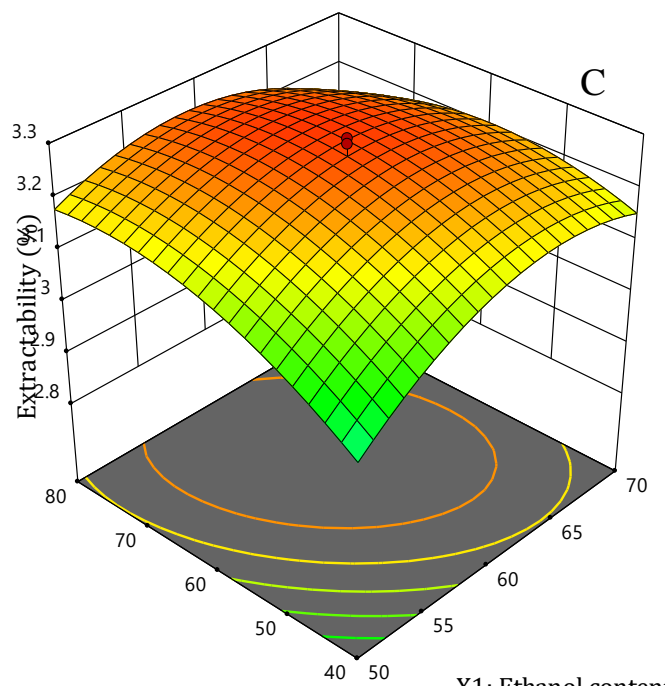

$\mathrm{X} 4$ : Temperature $\left({ }^{\circ} \mathrm{C}\right)$

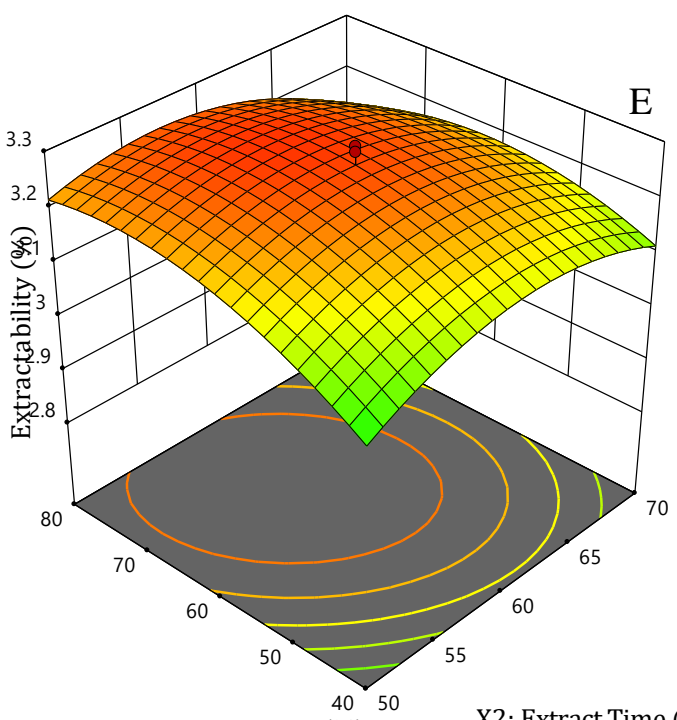

$\mathrm{X} 4$ : Temperature $\left({ }^{\circ} \mathrm{C}\right)$

X2: Extract Time (min)

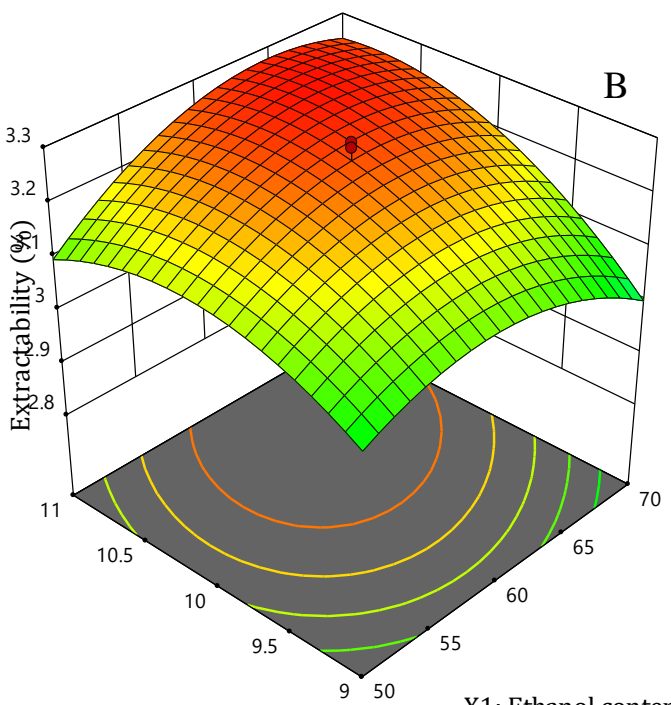

X3: Ratio of solid to liquid

X1: Ethanol content (\%)

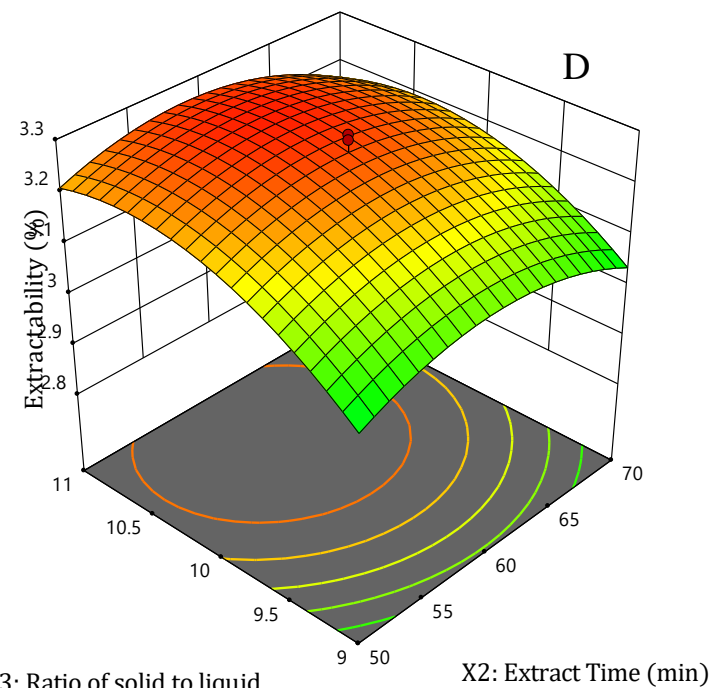

X3: Ratio of solid to liquid

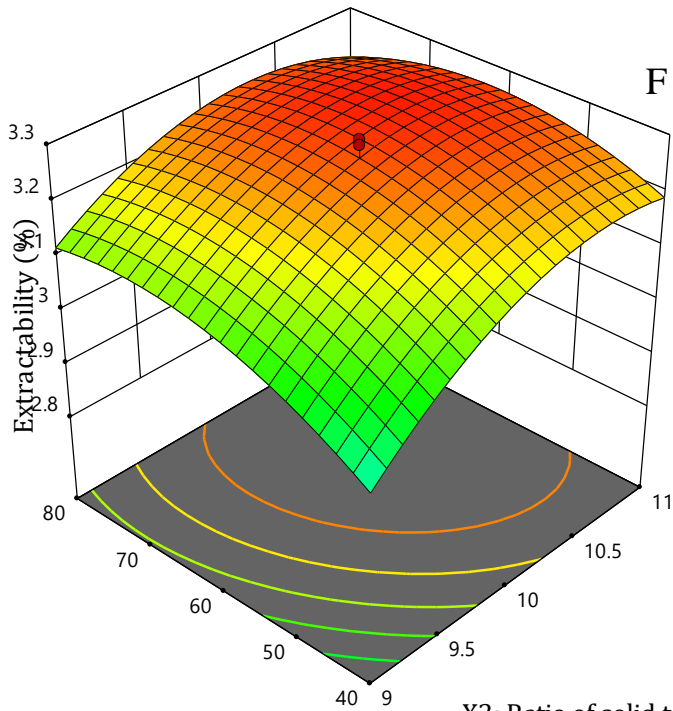

$\mathrm{X} 4$ : Temperature $\left({ }^{\circ} \mathrm{C}\right)$
X3: Ratio of solid to liquid

Figure 5. Response surface plots and contour lines of effects of interaction between each factor 
As can shown Figure 5B and 5C, the surface on the in teraction between each factor in this is the steepest, $\mathrm{n}$ ext steep is the surface on the interaction between eac $\mathrm{h}$ factor in Figure 5E and 5F. Therefore, the interinflu ence of the ethanol content and the ratio of solid to li quid and the interinfluence of the ethanol content an $\mathrm{d}$ the extraction temperature on the extractability is $\mathrm{h}$ igh significant, next significance is the interinfluence of the extraction temperature and the extraction time and the interinfluence of the extraction temperature a nd the ratio of solid to liquid. Thourgh the optimizing of AP extraction processing by response surface exper iment, determined that the optimal condition of its pr

ocess is the extraction solution concentration $62.8 \%, \mathrm{t}$ he extraction time $59 \mathrm{~min}$, the ratio of solid to liquid $1: 10.5$ and the extraction temperature $62^{\circ} \mathrm{C}$. Under th e optimum condition, the actual extratability is $3.21 \%$, which was not much different from the theoretical $\mathrm{v}$ alue of $3.29 \%$, were increased from extractability $2.27 \%$ in previous extractive method to $3.28 \%$.

\section{IV.DISCUSSION}

The extractability of andrographolide from the $A$. pan iculata by ultrasonic assisted extraction is improved, $\mathrm{t}$ he optimum condition for extracted the andrographol ide is determined by response surface experiment and detected the extractability of andrographolide under $t$ he optimum condition. As be shown Table 3 and Figu re 5, the main factors affecting the extractability of $A$ $\mathrm{P}$ were tested by response surface experiment, and the optimum extraction condition was determined. Acco rding above table and figure, the ratio of solid to liqui $\mathrm{d}$ and the extract temperature had high significant eff ects on the total extractabilty of diterpenoids $(\mathrm{p}<0.01)$, then the ethanol content had significant effects $(\mathrm{P}<0.0$ $5)$, and the extract time had no significant effects $(\mathrm{P}>0$. 05), and the interinfluence of the ethanol content and the ratio of solid to liquid and the interinfluence of $t$ he ethanol content and the extraction temperature on the extractability is high significant, next significance is the interinfluence of the extraction temperature an $d$ the extraction time and the interinfluence of the ext raction temperature and the ratio of solid to liquid. $\mathrm{T}$ hourgh the optimizing of AP extraction processing by response surface experiment, determined that the opt imal condition of its process is the extraction solution concentration $62.8 \%$, the extraction time $59 \mathrm{~min}$, the $\mathrm{r}$ atio of solid to liquid 1:10.5 and the extraction tempe rature $62^{\circ} \mathrm{C}$. Under the optimum condition, the actual extratability is $3.28 \%$, which was not much different from the theoretical value of $3.29 \%$, were increased fr om extractability $2.27 \%$ in previous extractive metho $\mathrm{d}$ to $3.28 \%$.

\section{CONCLUSION}

In this study, improved the extractability of andrographolide from the $A$. paniculata by ultrasonic assisted extraction, the optimum condition for extracted the andrographolide is determined by response surface experiment and detected the extractability of andrographolide under the optimum condition. By single factor analysis and response surface experiments, the optimum conditions for extracted the andrographolide were the extraction solution concentration $62.8 \%$, the extraction time $59 \mathrm{~min}$, the ratio of solid to liquid $1: 10.5$ and the extraction temperature $62^{\circ} \mathrm{C}$. Investigate the andrographolide extractability in the optimun extraction condition by HPLC were increased from $2.27 \%$ to $3.28 \%$.

\section{REFERENCES}

[1]. Patil R, Jain V. Andrographolide: A Review of Analytical Methods, Journal of Chromatographic Science, 2021, 59(2): 191-203.

[2]. Chia VV, Pang SF, Gimbun J. Mass spectrometry analysis of auxiliary energy-induced terpenes extraction from Andrographis Paniculata, Industrial Crops \& Products, 2020, 155: 1-7. 
[3]. Hancke Juan L. A double-blind, randomized, placebo-controlled study to assess the efficacy of Andrographis paniculata standardized extract (ParActin $\left.{ }^{\circledR}\right)$ on pain reduction in subjects with knee osteoarthritis, Phytotherapy Research. 2019, 33(5): 1469-1479.

[4]. Balap A, Lohidasan S , Sinnathambi A. Pharmacokinetic and pharmacodynamic interaction of andrographolide and standardized extract of Andrographis paniculata (Nees) with nabumetone in wistar rats, Phytotherapy research, 2017, 31(1): 75-80.

[5]. Pramanick S, Banerjee S, Achari B. Andropanolide and isoandrographolide, minor diterpenoids from Andrographis paniculata: structure and X-ray crystallographic analysis, Journal of Natural Products, 2006, 69(3): 403405.

[6]. Uchaipichat V. In vitro inhibitory effects of major bioactive constituents of Andrographis paniculata, Curcuma longa and Silybum marianum on human liver microsomal morphine glucuronidation: a prediction of potential herbdrug interactions arising from andrographolide, curcumin and silybin inhibition in humans, Drug Metabolism and Pharmacokinetics, 2018, 31(1): 67-76.

[7]. Wiart C, Kumar K, Yusof MY. Antiviral properties of ent-labdene diterpenes of Andrographis paniculata Nees, inhibitors of herpes simplex virus type 1, Phytotherapy research, 2005, 19(12): 1069-1070.

[8]. Yuan HH, Sun B, Gao F. Synergistic anticancer effects of andrographolide and paclitaxel against A549 NSCLC cells, Pharmaceutical Biology, 2016, 54(11): 2629-2635.

[9]. Gan L, Zheng YR, Deng LJ. Diterpenoid lactones with anti-inflammatory effects from the aerial parts of Andrographis paniculata, Molecules, 2019, 24(15): 1-17.

[10].Kandanur SGS, amang N, Golakoti NR. Andrographolide: A natural product template for the generation of structurally and biologically diverse diterpenes, European Journal of medicinal chemistry, 2019, 176: 513-533.

[11].Kim N, Lertnimitphun P, Jiang YW. Andrographolide inhibits inflammatory responses in LPS-stimulated macrophages and murine acute colitis through activating AMPK, Biochemical Pharmacology. 2019, 170: 1-17.

[12].Gao SY. Wang D, Chai H. Unusual ent-labdane diterpenoid dimers and their selective activation of TRPV channels, Journal of organicchemistry, 2019, 84(21): 13595-13603.

[13].Virendra Rathod, Priyanka Rao. Effect of Three Phase Extraction with Ultrasound on recovery and Antioxidant Activity of Andrographis paniculata, Journal of Biologically Active Products from Nature, 2015, 5(4): 264-275.

\section{Cite this article as :}

KiBong Kim, IlJin Kim, SongLok Uh, YongIl Seo, CholKwang Li, UnHyang Lyeom, KwangRyel Hwang, " Study on the Optimization for the Extraction Process of Andrographolide by Ultrasonic Assisted Extraction, International Journal of Scientific Research in Science, Engineering and Technology(IJSRSET), Print ISSN : 2395-1990, Online ISSN : 2394-4099, Volume 8, Issue 2, pp.08-17, March-April-2021. Available at doi : https://doi.org/10.32628/IJSRSET21824 